\title{
Expression of the Thermobifida fusca xylanase Xyn11A in Pichia pastoris and its characterization
}

\author{
Longmei Zhao, Jiang Geng, Yaoqi Guo, Xiudong Liao, Xuhui Liu, Rujuan Wu, Zhaojun Zheng and Rijun Zhang*
}

\begin{abstract}
Background: Xylan is a major component of plant cells and the most abundant hemicellulose. Xylanases degrade

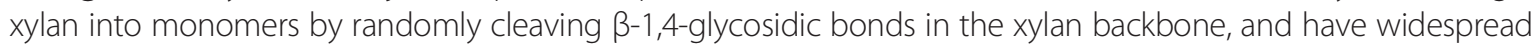
potential applications in various industries. The purpose of our study was to clone and express the endoxylanase gene xynA of Thermobifida fusca YX in its native form and with a C-terminal histidine (His) tag in Pichia pastoris X-33. We analyzed and compared these two forms of the protein and examined their potential applications in various industries.

Results: The xynA gene from T. fusca YX was successfully cloned and expressed using P. pastoris X-33. We produced a recombinant native form of the protein ( $r X y n 11 A)$ and a C-terminal His-tagged form of the desired protein (rXyn11A-(His) 6). The specific activities of rXyn11A and rXyn11A-(His) $)_{6}$ in culture supernatants approached 149.4 and $133.4 \mathrm{U} / \mathrm{mg}$, respectively. These activities were approximately 4 - and 3.5-fold higher than those for the non-recombinant wild-type Xyn11A (29.3 U/mg). Following purification, the specific activities of rXyn11A and rXyn11A-(His) 6 were 557.35 and 515.84

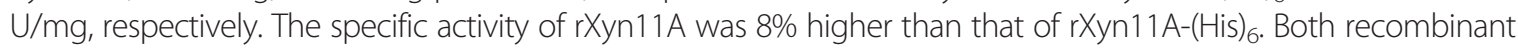
xylanases were optimally active at $80^{\circ} \mathrm{C}$ and $\mathrm{pH} 8.0$, and exhibited greater than $60 \%$ activity between $\mathrm{pH} 6-9$ and $60-80^{\circ} \mathrm{C}$. They exhibited similar pH stability, while rXyn11A exhibited better thermostability; N-glycosylation enhanced the thermostability of both recombinant xylanases. The products of beechwood xylan hydrolyzed by both xylanases included xylobiose, xylotriose, xylotetraose and xylopentaose.

Conclusions: The C-terminal His tag had adverse effects when added to the Xyn11A protein. The thermostability of both recombinant xylanases was enhanced by $\mathrm{N}$-glycosylation. Their stabilities at a high $\mathrm{pH}$ and temperature indicate their potential for application in various industries.
\end{abstract}

Keywords: Thermobifida fusca Xyn11A, Pichia pastoris, Expression, C-terminal His-tag, Characterization, Glycosylation

\section{Background}

Xylan, the major component in plant cells and the most abundant hemicellulose, is composed of $\beta-1,4$-linked xylopyranosyl residues $[1,2]$. Recently, lignocellulose, the most plentiful renewable biomass produced from photosynthesis, has attracted worldwide attention as a raw material for bioconversion [3]. Degrading all components of lignocellulose requires the synergistic activity of a large variety of enzymes with different specificities, such as exo-1,4- $\beta$-glucanases, endo-1,4- $\beta$-glucanases, $\beta$-glucosidases, endo-xylanases, pectin methyl esterases, and laccase [4].

Among these, xylanases ( $\beta$-1,4-Endoxylanases, EC 3.2.1.8) are the core enzymes responsible for the degradation of

\footnotetext{
* Correspondence: feedbiotech@yahoo.com

Laboratory of Feed Biotechnology, State Key Laboratory of Animal Nutrition, College of Animal Science and Technology, China Agricultural University, Beijing 100193, China
}

(c) 2015 Zhao et al.; licensee BioMed Central. This is an Open Access article distributed under the terms of the Creative Commons Attribution License (http://creativecommons.org/licenses/by/4.0), which permits unrestricted use, distribution, and reproduction in any medium, provided the original work is properly credited. The Creative Commons Public Domain Dedication waiver (http://creativecommons.org/publicdomain/zero/1.0/) applies to the data made available in this article unless otherwise stated. xylan into monomers through the random cleavage of $\beta$-1,4-glycosidic bonds in the xylan backbone [4,5]. Xylanases have widespread potential applications in the textile, feed, beverage, and biofuel industries [2,6-10]; moreover, they form a major group of industrial enzymes used in the paper and pulp industry. The release of lignin from paper pulp can be facilitated by the hydrolysis of xylan [2]. Xylanases can facilitate the hydrolysis of lignocellulosic substrates as xylanases ameliorate the "blocking effect" of xylan, one of the major mechanisms that limits the accessibility of cellulose to cellulase enzymes. Xylanases also interact synergistically with cellulases to improve cellulose accessibility by increasing fiber swelling and porosity [11].

According to amino acid sequences, structural folds, and catalytic mechanisms, xylanases are classified into glycoside hydrolases $(\mathrm{GH})$ families $5,7,8,10,11$, and 43 [12-14]. An industrially suitable xylanase should have 
certain specific properties; for example, high activity and stability at high temperatures $\left(>70^{\circ} \mathrm{C}\right)$ or at high $\mathrm{pH}$ (>8.0) [15]. Thermobifida fusca is a thermophilic actinomycete and a major degrader of plant cell walls in heated organic materials such as compost piles and rotting hay [16]. The xylanase Xyn $11 \mathrm{~A}$, from T. fusca, belongs to the G (11) family and contains a substratebinding domain. Xyn11A has thermostable properties, unique among family $G$ xylanases, that are especially useful for industrial purposes [17].

The yeast Pichia pastoris is an excellent and efficient system for the expression of secreted and intracellular proteins [18]. A number of xylanases from a variety of organisms have been cloned and expressed in P. pastoris [19-25]. Some xylanases have been cloned and expressed in the bacterium Escherichia coli [20,26-28]. A comparison of expression levels and the activities of products in P. pastoris and $E$. coli revealed that expression levels of active proteins in P. pastoris were much higher than those in E. coli [29]. Recombinant proteins produced in $P$. pastoris were very easily $\mathrm{N}$-glycosylated via post-translational modification, although the properties of glycosylated proteins were not always distinct from unglycosylated proteins. The thermostability of recombinant proteins can be decreased or increased after glycosylation [29,30].

We selected the $x y n A$ gene encoding Xyn11A from T. fusca YX for cloning and expression in P. pastoris. To facilitate the purification of recombinant proteins, some of the proteins were fused to a polyhistidine tag (His) at the C-terminus [31]; however, recombinant proteins containing a His-tag can differ from their wild-type counterparts with respect to dimerization or oligomerization properties [32]. We therefore also attempted to express $x y n A$ in its native form in a $P$. pastoris expression system and compared the properties of the native form with those of the His-tagged form.

\section{Results and discussion}

\section{Analysis of $x y n A$ gene from $T$. fusca genomic DNA}

We amplified an 891-bp DNA fragment encoding the mature Xyn11A peptide (296 aa) by polymerase chain reaction (PCR) from the genomic DNA of T. fusca YX using primers $(x y A-f, x y A-r, x y A-h i s-r)$. The fragment was then successfully cloned into the pMD19-T vector (TaKaRa, Dalian, China). According to the Xyn11A protein sequence (GenBank Accession Number U01242), the mature Xyn11A peptide comprises a 189-aa catalytic domain (CD), an 86-aa xylan binding domain (XBD), and a 21-aa Gly-Pro-rich region that connects the CD and XBD [17]. The nucleotide and corresponding aa sequences of Xyn11A are shown in Figure 1. Based on previous studies, there were seven possible $\mathrm{N}$-glycosylation sites (Asn-X-Ser/Thr) [33], with very little O-linked glycosylation observed in $P$. pastoris [34]. Supposing that all of the possible
$\mathrm{N}$-glycosylations occurred and the average glycosylated side chain was $\operatorname{Man}_{10}$ GlcNAc [34], then the molecular mass of the target protein would increase by about $12.9 \mathrm{kDa}$ compared with the native wild-type Xyn11A (31.9 kDa).

\section{Expression of recombinant Xyn11A and Xyn11A-(His) ${ }_{6}$ in $P$. pastoris}

The pPICZ $\alpha-x y n A$ and $p P I C Z \alpha-x y n A-(H i s)_{6}$ expression plasmids were successfully generated as described in Methods. The coding sequences for Xyn11A and Xyn11A$(\mathrm{His})_{6}$ were cloned in frame with the $\alpha$-factor signal sequence in the $P$. pastoris-E. coli shuttle vector pPICZ $\alpha-\mathrm{A}$. After confirmation by sequencing, the recombinant plasmids were linearized using restriction endonuclease PmeI and electroporated into P. pastoris X-33. The pPICZ $\alpha-\mathrm{A}$ vector was used as a negative control and transformed into P. pastoris X-33. Transformants harboring $\mathrm{pPICZ} \alpha-x y n A$ or pPICZ $\alpha-x y n A-(\mathrm{His})_{6}$ were grown on YPDS agar plates containing $100 \mu \mathrm{g} / \mathrm{mL}$ Zeocin and selected for high resistance to Zeocin $(2000 \mu \mathrm{g} / \mathrm{mL})$; successful transformants were obtained.

The pPICZ $\alpha-x y n A$ or pPICZ $\alpha-x y n A-(H i s)_{6}$ plasmids carrying the $x y n A$ gene were regulated by an alcohol oxidase gene promoter that could be induced by $0.5 \%(\mathrm{v} / \mathrm{v})$ methanol. The maximum activities of recombinant Xyn11A (rXyn11A) and recombinant Xyn11A-(His) 6 (rXyn11A(His) $)_{6}$ ) in BMMY medium reached 1157.63 and 964.97 $\mathrm{U} / \mathrm{mL}$, respectively, after $96 \mathrm{~h}$ of cultivation. The specific activity of a crude preparation of rXyn11A (149.4 U/mg) was about $12 \%$ higher than that of rXyn11A-(His) ${ }_{6}(133.4$ $\mathrm{U} / \mathrm{mg}$ ). The C-terminal His tag was located behind the XBD which was not essential for efficient hydrolysis of soluble xylan[17], therefore the C-terminal His tag affected the activity of rXyn11A-(His) 6 through its dimerization or oligomerization properties [32].

Several protein bands corresponding to a molecular mass of about $45 \mathrm{kDa}$ were observed as the major protein in supernatants from $P$. pastoris/pPICZ $\alpha-x y n A$ and $P$. pastoris/ pPICZ $\alpha-x y n A-(H i s)_{6}$ cultures. This protein was not detected in the supernatant of $P$. pastoris cultures transformed with pPICZ $\alpha-\mathrm{A}$ (Figure 2). These $45-\mathrm{kDa}$ proteins accumulated in supernatants obtained at different culture times (Figure 2). The molecular mass of native wild-type Xyn11A should be $31.9 \mathrm{kDa}$ [17]; however, activity assays revealed that these $45-\mathrm{kDa}$ proteins possessed xylanase activity (Figure 3), and thus we assign them as the recombinant xylanases with some glycosylated side chains. Xylanase activity was not detected in the supernatant of $P$. pastoris transformed with pPICZ $\alpha-\mathrm{A}$. These results were consistent with those from previous studies, indicating the generation of several glycosylated proteins [15,34]. A separate protein band (Figure 3B, arrows) was thought to be the proteolytic degradation product of recombinant xylanase including the CD. The target proteins rXyn11A and rXyn11A-(His) 6 


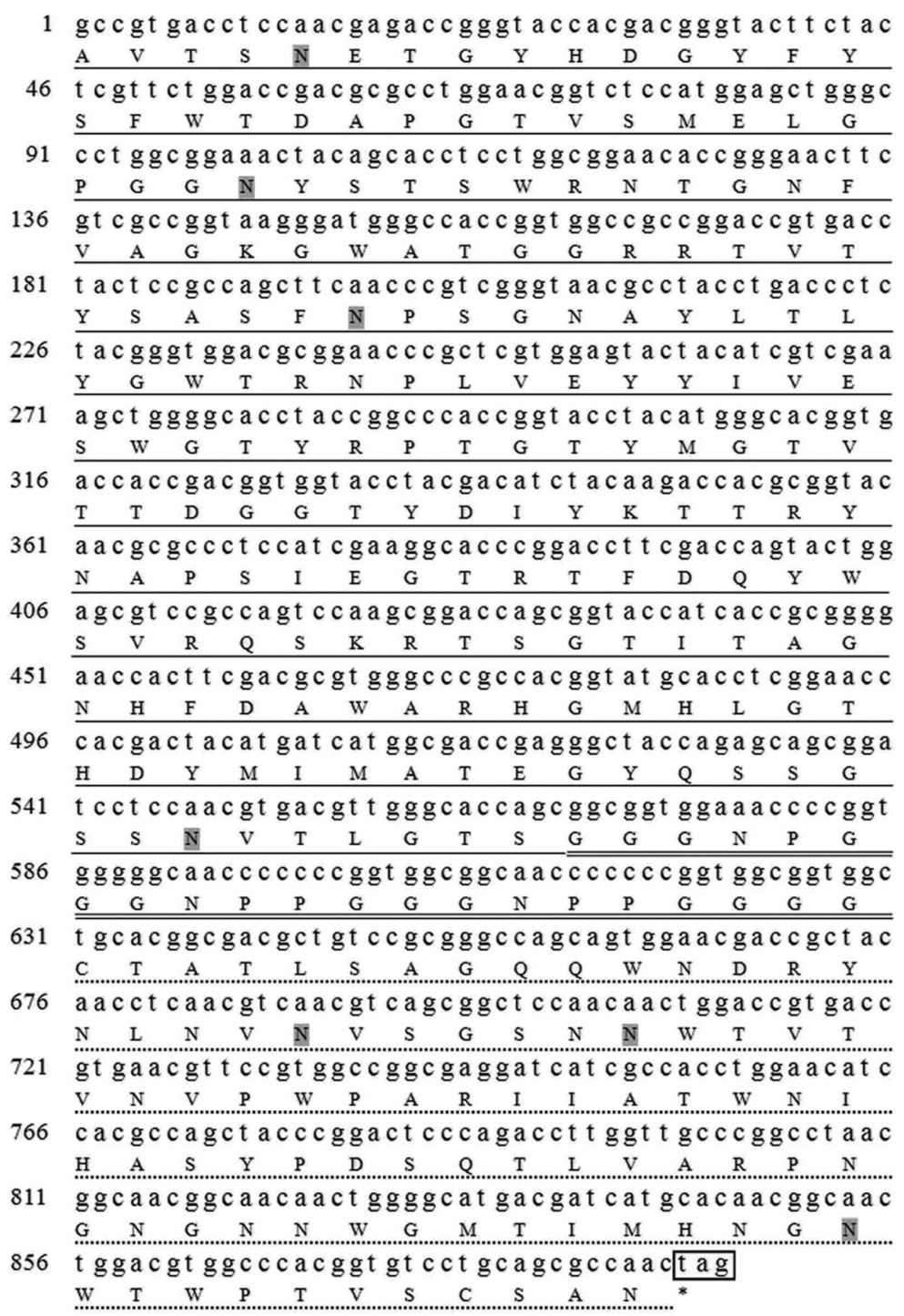

Figure 1 Nucleotide sequence and corresponding amino acid sequence of the Xyn11A from $T$. fusca YX. The catalytic domain of Xyn11A is underlined. The xylan binding domain of Xyn11A is indicated by a dotted underline. The Gly-Pro-rich linker region is double underlined. Seven putative $\mathrm{N}$-glycosylation sites are highlighted in grey. The stop codon is boxed and marked by asterisk (*).

constituted up to 63.7 and $62.3 \%$, respectively, of all soluble proteins in supernatants as determined by Bandscan 5.0 software (Glyko, Novato, CA, USA).

\section{Purification of recombinant xylanases}

Purification of the recombinant proteins was performed as described in Methods, and a summary is presented in Table 1. The rXyn11A and rXyn11A-(His) 6 were purified 3.7-fold and 3.9-fold to homogeneity with recovery yields of $8.5 \%$ and $19.8 \%$, respectively. The purification fold was not high because the recombinant xylanases constituted so much of the total protein in the supernatants (Figure 2). The specific activity of rXyn11A was $557.35 \mathrm{U} / \mathrm{mg}$ while that of rXyn11A-(His) 6 was $515.84 \mathrm{U} / \mathrm{mg}$. Purified fractions of rXyn11A and rXyn11A-(His) 6 were subjected to $15 \%$ sodium dodecyl sulfate polyacrylamide gel electrophoresis (SDS-PAGE) and revealed several protein bands with molecular masses of about $45 \mathrm{kDa}$, which were distinct from the molecular mass of wild-type Xyn11A (31.9 kDa) and the calculated molecular mass of rXyn11A-(His) 6 (32.7 kDa), respectively (Figure 4).

Although rXyn11A-(His) ${ }_{6}$ could be purified to homogeneity with a simpler procedure than rXyn11A, the latter exhibited higher specific activity than the former, consistent with results from a previous study where it was shown that the recombinant native form of cellulase was more active and stable than a C-terminal His-tagged cellulase produced in E. coli [35]. 


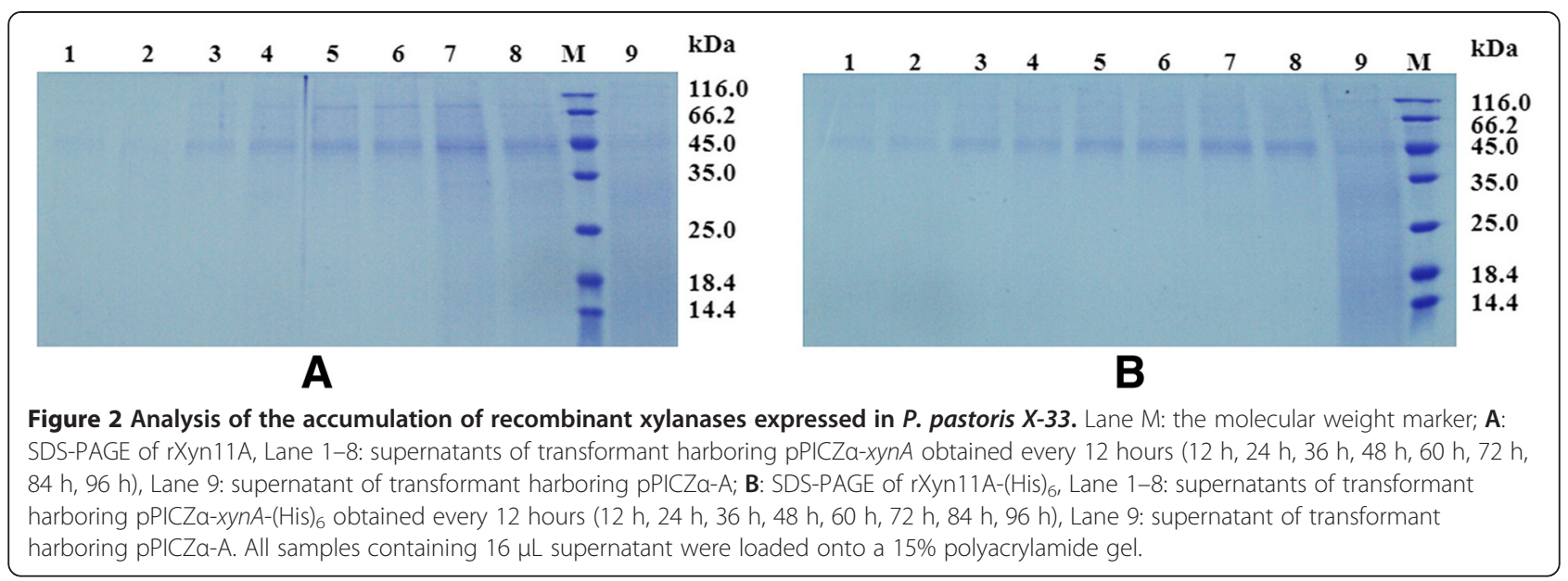

\section{Characterization of the recombinant xylanases}

Both rXyn11A and rXyn11A-(His) 6 were optimally active at $\mathrm{pH}$ 8.0, and exhibited $>60 \%$ activity between $\mathrm{pH}$ 6.0-9.0 (Figure 5A). Optimal activity was seen at $80^{\circ} \mathrm{C}$, with $>60 \%$ activity between 60 and $80^{\circ} \mathrm{C}$ (Figure 5B). Activities increased as the temperature rose, resulting in maximum activity at $80^{\circ} \mathrm{C}$, and then decreased rapidly when the temperature increased above $80^{\circ} \mathrm{C}$. The residual activities of both recombinant xylanases were $>60 \%$ over a broad $\mathrm{pH}$ range (3.0-10.0), indicating their stability and that they would be of great practical use in various industrial applications (Figure 5C). The rXyn11A xylanase exhibited $>80 \%$ residual activity between 30 and $80^{\circ} \mathrm{C}$, while rXyn11A(His) ${ }_{6}$ exhibited $57 \%$ residual activity at $80^{\circ} \mathrm{C}$ (Figure $5 \mathrm{D}$ ). After incubation at $90^{\circ} \mathrm{C}$ for $30 \mathrm{~min}$, rXyn11A and rXyn $11 \mathrm{~A}-(\mathrm{His})_{6}$ retained more than $10 \%$ of their initial activities (Figure 5D). We observed $>20 \%$ residual activity for rXyn11A and rXyn11A-(His) $)_{6}$ after treatment at $90^{\circ} \mathrm{C}$ for $10 \mathrm{~min}$ (Figure $5 \mathrm{E}$ and $\mathrm{F}$ ). Both of the recombinant xylanases showed better thermal stabilities than the native wild-type Xyn11A from T. fusca [17]. Compared with results in a previous study regarding the same xylanase that was not glycosylated in P. pastoris [36], rXyn11A and rXyn11A-(His) 6 exhibited greater thermostability, possibly because of glycosylation of the recombinant xylanases.

\section{Analysis of deglycosylation}

Analysis of rXyn11A and rXyn11A-(His) 6 by SDS-PAGE revealed that their molecular weights (about $45 \mathrm{kDa}$ ) were increased by about $13 \mathrm{kDa}$ compared with the native wild-type Xyn11A (31.9 kDa; Figure 4). Following treatment with endo- $\mathrm{H}$ to remove carbohydrate moieties, a protein band was observed at about $32 \mathrm{kDa}$ by SDS-PAGE (Figure 4). These findings suggested that $\mathrm{N}$-glycosylation of rXyn11A and rXyn11A-(His) 6 accounted for about $13 \mathrm{kDa}$.

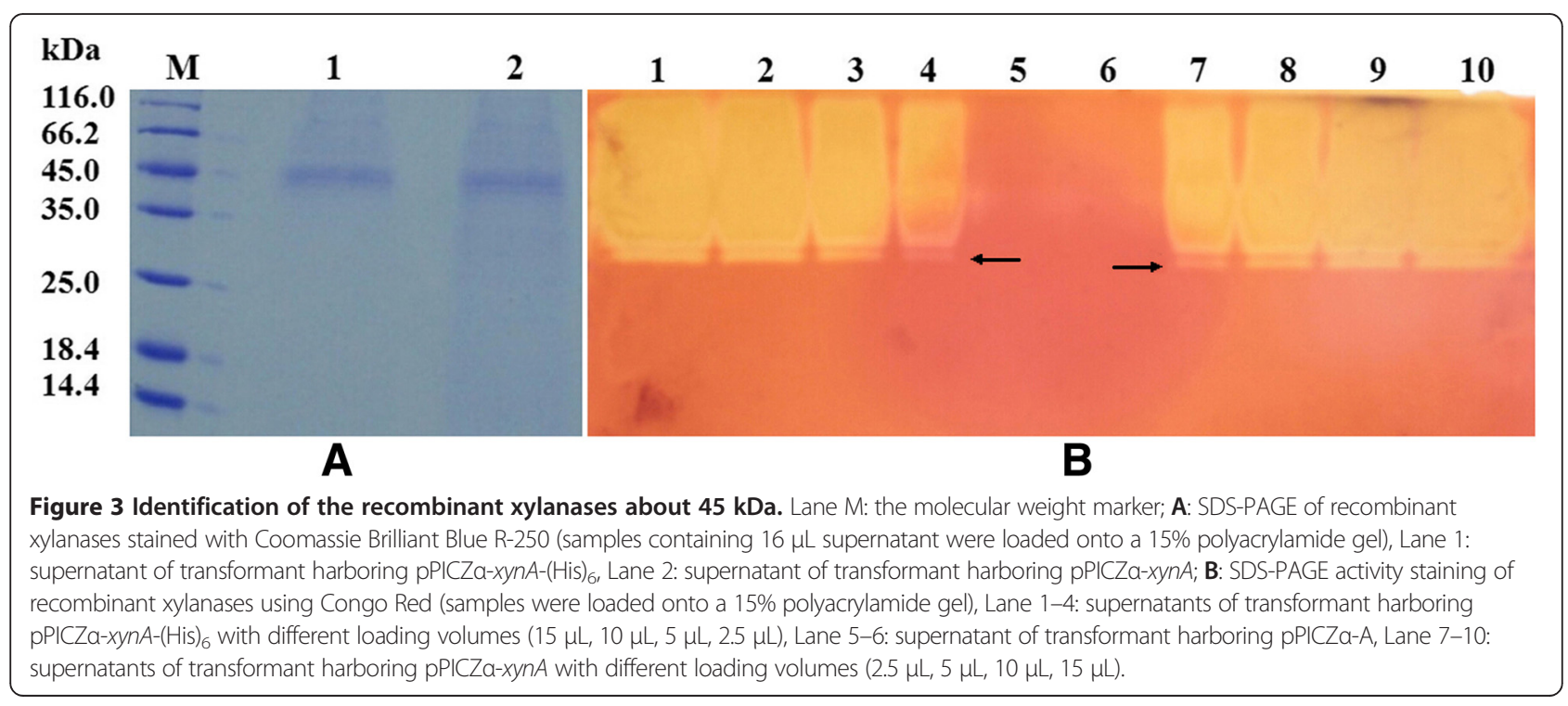


Table 1 Summary of the purification of rXyn11A and rXyn11A-(His) 6

\begin{tabular}{|c|c|c|c|c|c|}
\hline Purification steps & Total activity (U) & Total protein $(\mathrm{mg})$ & Specific activity $\left(\mathrm{U} \cdot \mathrm{mg}^{-1}\right)$ & Purification (fold) & Yield (\%) \\
\hline \multicolumn{6}{|c|}{ P. pastoris X-33/pPICZa-xynA } \\
\hline The supernatant & 11576.3 & 77.5 & 149.4 & 1 & 100 \\
\hline Sephadex G-25 & 9205.5 & 36.1 & 254.9 & 1.7 & 79.5 \\
\hline Mono Q 5/50 GL & 2462.3 & 6.3 & 390.2 & 2.6 & 21.3 \\
\hline Ultrafiltration & 979.3 & 1.8 & 557.4 & 3.7 & 8.5 \\
\hline \multicolumn{6}{|c|}{ P. pastoris X-33/pPICZa-xynA-(His) 6} \\
\hline The supernatant & 9649.7 & 72.4 & 133.4 & 1 & 100 \\
\hline Ni-NTA agarose & 3057.0 & 15.8 & 193.6 & 1.5 & 31.7 \\
\hline Ultrafiltration & 1908.6 & 3.7 & 515.8 & 3.9 & 19.8 \\
\hline
\end{tabular}

Both the deglycosylated rXyn11A and rXyn11A-(His) 6 showed optimal activities at $70^{\circ} \mathrm{C}$ and $\mathrm{pH} 7.0$ (Figure 6A and $\mathrm{B})$, which were decreased compared with the $\mathrm{N}$ glycosylated recombinant xylanases $\left(80^{\circ} \mathrm{C}\right.$ and $\left.\mathrm{pH} 8.0\right)$. The deglycosylated xylanases showed similar $\mathrm{pH}$ stability to the $\mathrm{N}$-glycosylated recombinant xylanases (Figure $6 \mathrm{C}$ ), but the thermostability was decreased. After incubation at $80^{\circ} \mathrm{C}$ and $90^{\circ} \mathrm{C}$ for $30 \mathrm{~min}$, deglycosylated rXyn11A and rXyn11A-(His) 6 retained less than $30 \%$ and $5 \%$ of their initial activities (Figure 6D), respectively. SDS-PAGE of deglycosylated rXyn11A and rXyn11A-(His) 6 without denaturation showed that $\mathrm{rXyn} 11 \mathrm{~A}-(\mathrm{His})_{6}$ was not thoroughly deglycosylated (Figure 7 ), thus the change in thermostability of rXyn11A-(His) 6 was less than that for rXyn11A. The C-terminal His tag did not have a major effect on the activity and stability of recombinant xylanase after deglycosylation (Figure 6).

The recombinant xylanases had higher optimum temperatures and exhibited better thermostability, possibly because of $\mathrm{N}$-glycosylation. Our results corresponded with those in a previous study that showed that the
$\mathrm{N}$-glycosylation of recombinant enzymes expressed in $P$. pastoris enhanced their thermal stabilities [29,30,37].

Based on the amino acid sequence of mature Xyn11A (Figure 1), there appear to be seven potential N-glycosylation sites (N-X-S/T: NET 5-7, NYS 34-36, NPS 66-68, NVT 183-185, NVS 230-232, NWT 236-238, NWT 285-287); these sites were predicted by NetNGlyc 1.0Server (http://www.cbs.dtu.dk/services/ NetNGlyc/). Among these N-glycosylation sites, the first four were located within the $C D$ and the last three sites were within the XBD. There were six sites (NET 5-7, NYS 34-36, NVT 183-185, NVS 230-232, NWT 236-238, NWT 285-287) with $>54 \%$ probability of being glycosylated. A possible explanation for the higher thermostability caused by glycosylation may be that the long outer chains added during glycosylation can affect the folding or function of a foreign protein in $P$. pastoris [33]. In this study, the optimum $\mathrm{pH}$ was altered from 7.0 to 8.0 and the optimum temperature increased from $65^{\circ} \mathrm{C}$ to $80^{\circ} \mathrm{C}$. These changes may be attributable to the four $\mathrm{N}$-glycosylation sites located within the CD. To investigate the relationship

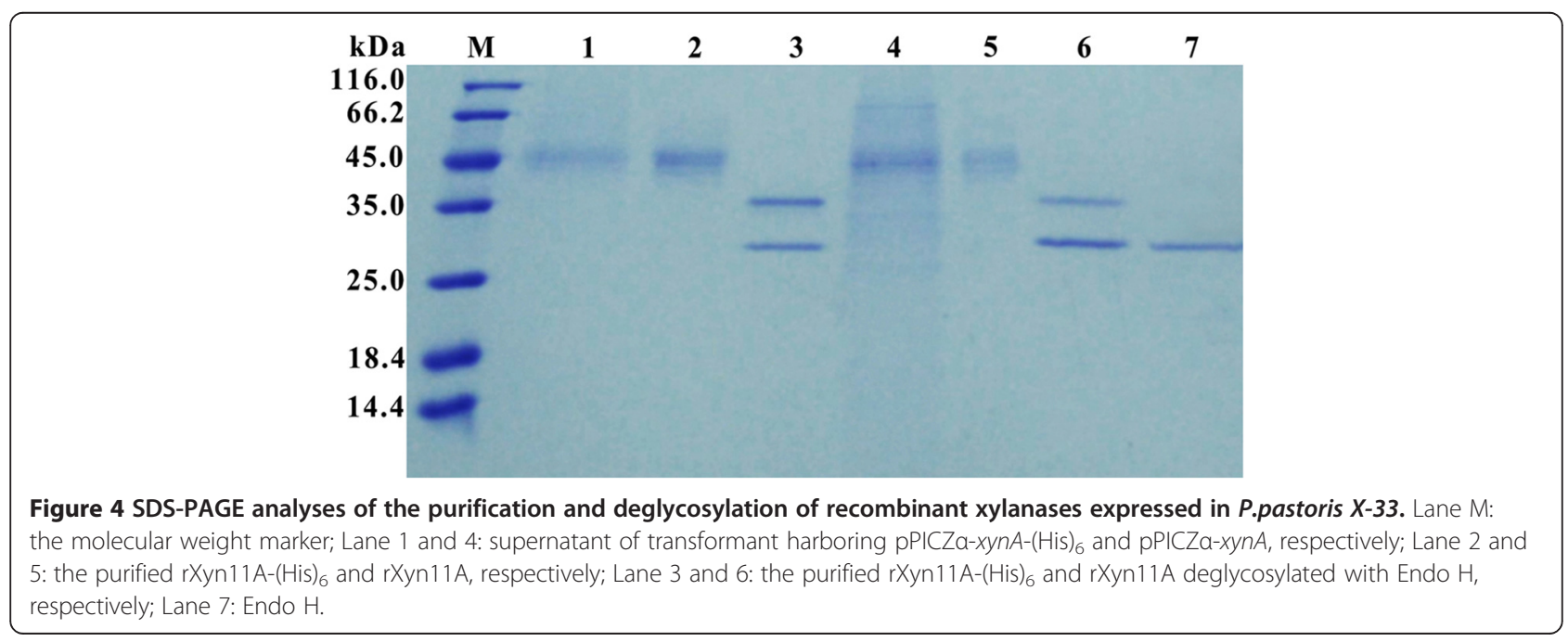




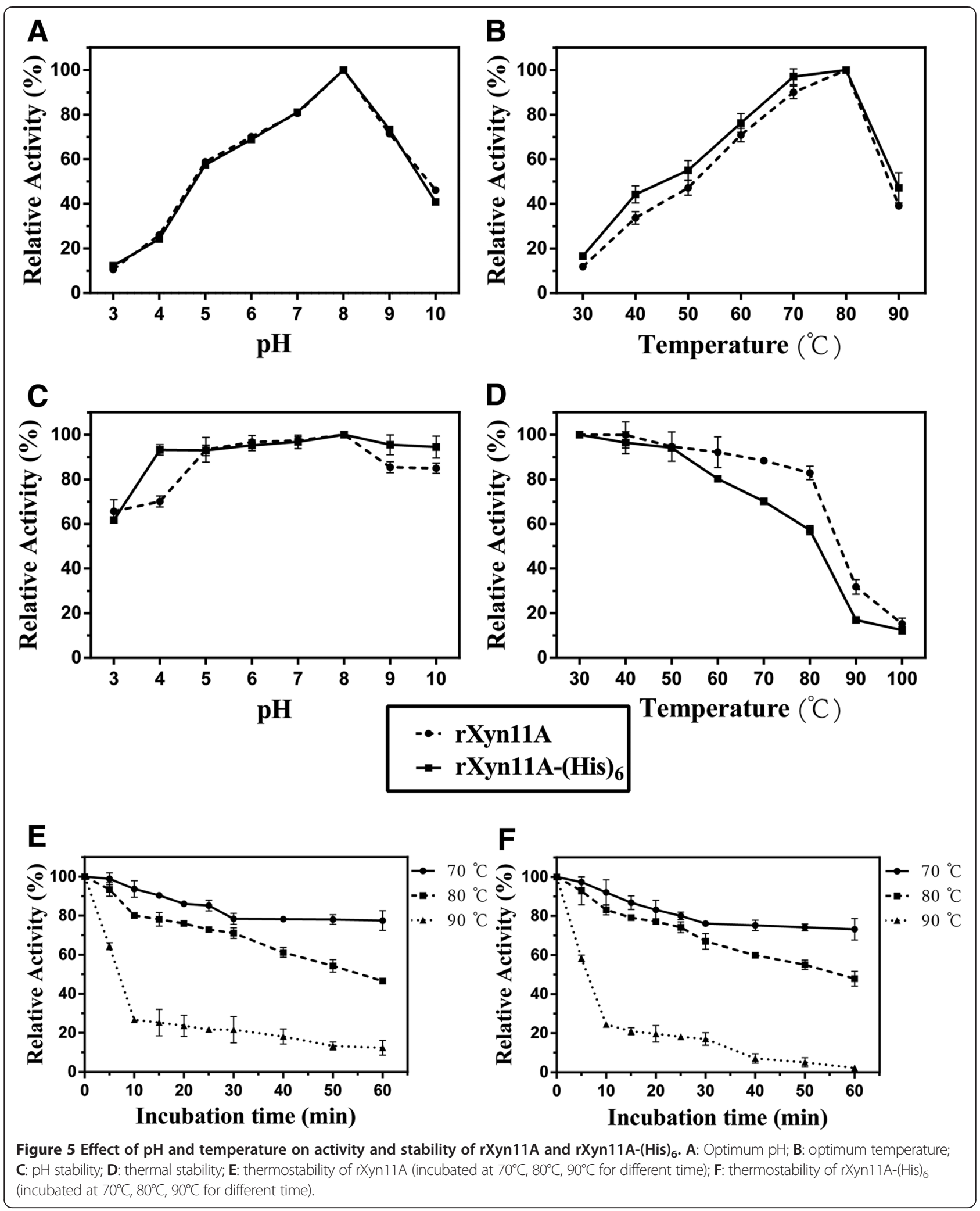

between $\mathrm{N}$-glycosylation and xylanase thermostability, we used Swiss Model to perform homology-modelling of Xyn11A (1-187 AA, the catalytic domain). There are one $\alpha$-helix and several $\beta$-sheets in this domain (Figure 8A), and the $\beta$-sheets form a groove (Figure $8 \mathrm{~B}$ ) which houses the active site [38]. Several potential N-glycosylation sites 

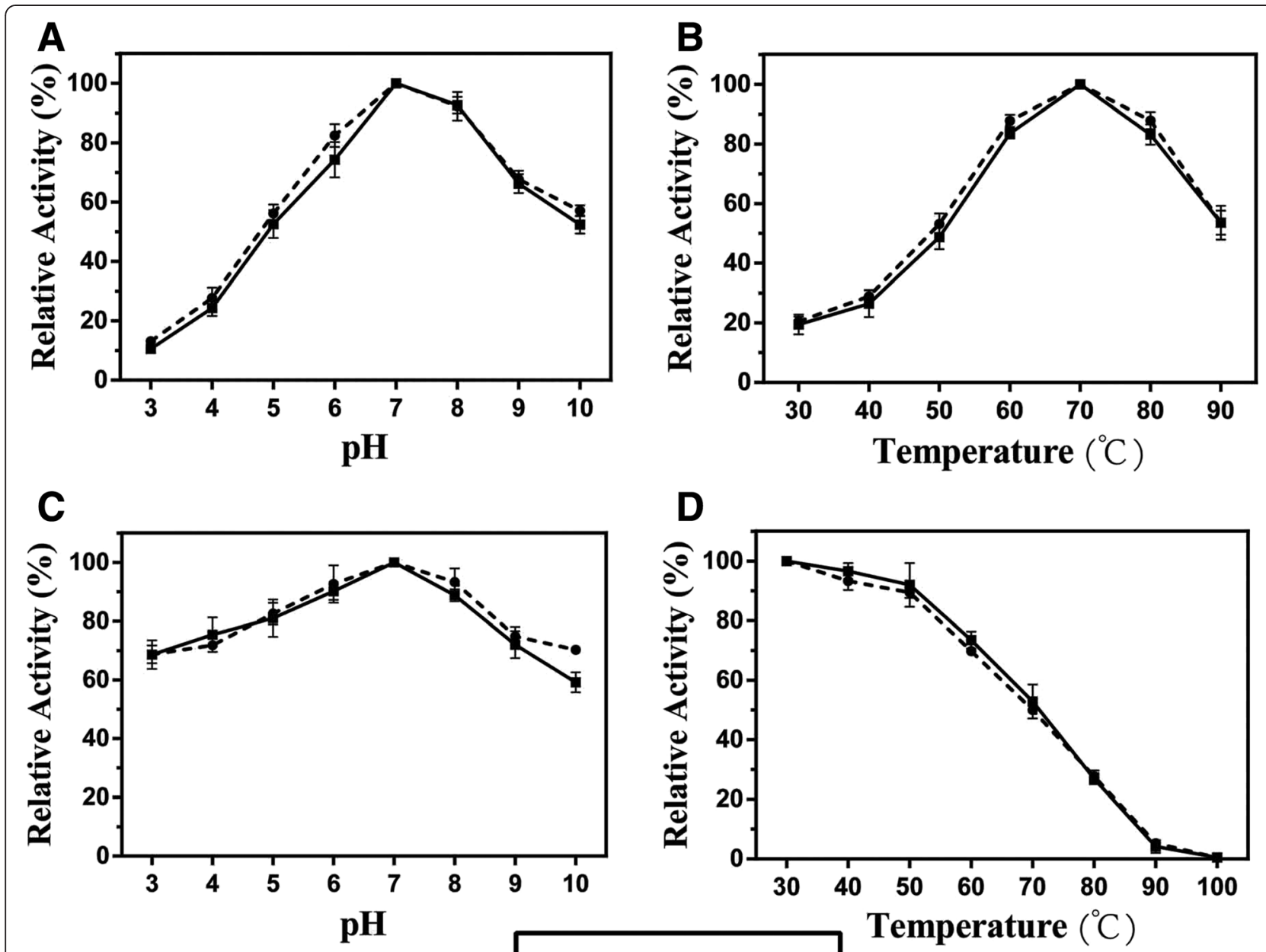

-• rXyn11A

- rXyn11A-(His) 6

Figure 6 Effect of $\mathrm{pH}$ and temperature on activity and stability of deglycosylated rXyn11A and rXyn11A-(His) 6 . A: Optimum pH; B: optimum temperature; $\mathbf{C}$ : pH stability; $\mathbf{D}$ : thermal stability.

were just included in the catalytic domain. Furthermore, it is believed that thermostable enzymes usually contain a large number of surface polar residues which generate more water-mediated networks surrounding the enzyme [38]. Therefore, the thermostability of rXyn11A and rXyn11A-(His) 6 may be increased by $\mathrm{N}$-glycosylation. The glycosylation of recombinant proteins alters some properties of the protein but not to a great extent $[15,39]$; in certain cases glycosylation can adversely affect thermostability in $P$. pastoris [29]. In a study examining the same xylanase, it was seen that when the linearized pPIC9K-tfx plasmid was transformed into P. pastoris GS115 after the xylanase gene was cloned into the vector, the expressed recombinant xylanase was not glycosylated and was the same size as the native xylanase [36]. These results showed that the difference between plasmids, as well as protein properties, may affect the glycosylation of recombinant proteins expressed in P. pastoris.

\section{Analysis of hydrolytic products}

The products of beechwood xylan hydrolyzed by rXyn11A and rXyn11A-(His) 6 were analyzed using thin-layer chromatography (TLC) (Figure 9) and high-performance ion chromatography (HPIC) (Table 2). For TLC, a series of oligosaccharides with a degree of polymerization of two and above were observed on the silica gel plate. The main hydrolytic products were X2-X5, while many higher oligomers were still present in the digest. During hydrolysis, the concentrations of xylooligosaccharides increased for $4 \mathrm{~h}$ and then decreased as the xylooligosaccharides were hydrolyzed by the recombinant xylanases (Figure 9). The HPIC results revealed that $\mathrm{rXyn} 11 \mathrm{~A}$ is better at hydrolyzing beechwood xylan than $\mathrm{rXyn} 11 \mathrm{~A}-(\mathrm{His})_{6}$. These findings 


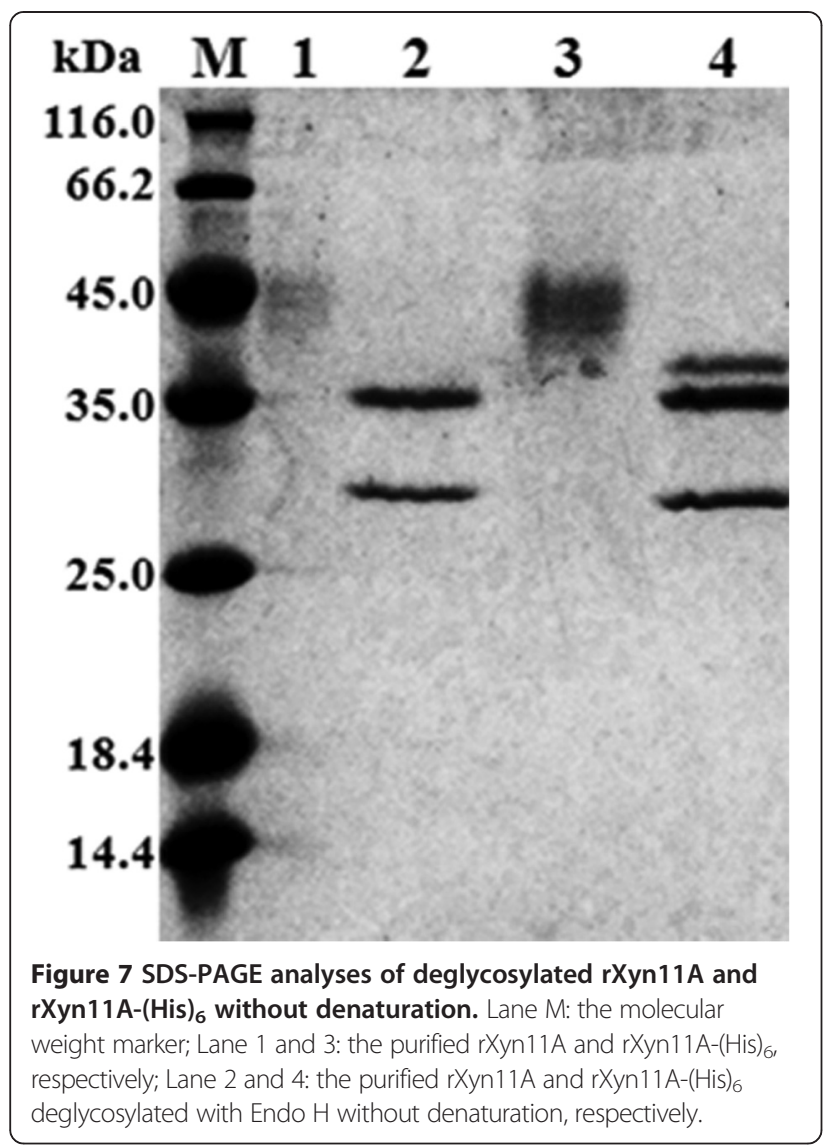

imply that the C-terminal His tag probably has adverse effects on xylanase activity. The C-terminal His tag may alter the structure of recombinant xylanases. The TLC and HPIC analyses showed that the main hydrolytic products were higher oligomers than xylose. Even after $24 \mathrm{~h}$, there was little xylose released via hydrolysis. Therefore, our results indicate that $\mathrm{rXyn} 11 \mathrm{~A}$ and $\mathrm{rXyn} 11 \mathrm{~A}-(\mathrm{His})_{6}$ hydrolyzed xylan by cleaving the intramolecular glycosidic bonds of xylooligosaccharides, as they are both endoxylanases [17]. The distribution pattern of hydrolytic products was identical for rXyn11A and rXyn11A-(His) 6 .

\section{Conclusions}

We have described the cloning and expression of a xylanase from $T$. fusca, and compared the characteristics of the recombinant wild-type xylanase, and the xylanase with a C-terminal His tag, expressed in P. pastoris. The characteristics of rXyn11A and rXyn11A-(His) 6 were similar with respect to thermostability and $\mathrm{pH}$ tolerance. The activity of rXyn11A was higher than that of rXyn11A-(His) $)_{6}$, with both their activities higher than that of native Xyn11A. Therefore, we conclude that the C-terminal His tag had adverse effects on enzyme activity. N-glycosylation enhanced the thermostability of the recombinant xylanases, suggesting they could be applied to the degradation of cellulosic materials and in other industries.

\section{Methods}

Chemicals and enzymes

Restriction endonucleases, T4 DNA Ligase and Endoglycosidase $\mathrm{H}$ (Endo $\mathrm{H}$ ) were purchased from New England Biolabs (Ipswich, MA, USA). Yeast extract and peptone were obtained from OXOID (Basingstoke, Hampshire, $\mathrm{UK})$, yeast nitrogen base (YNB) without amino acids was purchased from BD (Sparks, MD, USA), biotin was obtained from Amersco (Solon, OH, USA), and Zeocin was purchased from Invitrogen (San Diego, CA, USA). Ni-NTA agarose and silica gel plates 60 F 254 was purchased from Merck (Darmstadt, Germany). Beechwood xylan was purchased from Sigma Chemical Company (St. Louis, MO, USA). Xylose (X1) was from Wako (Osaka,

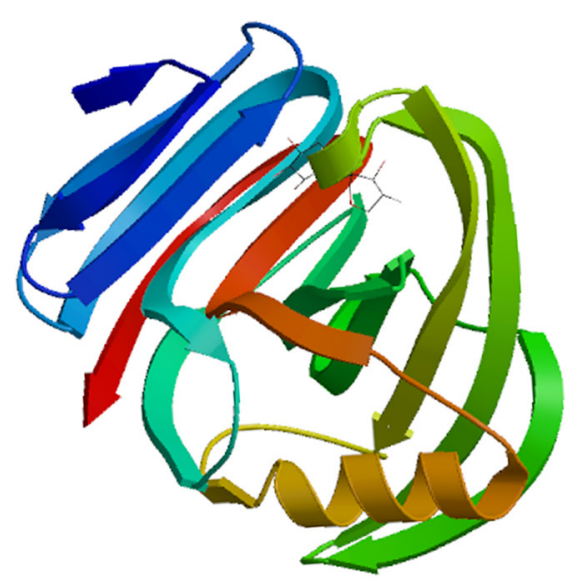

A

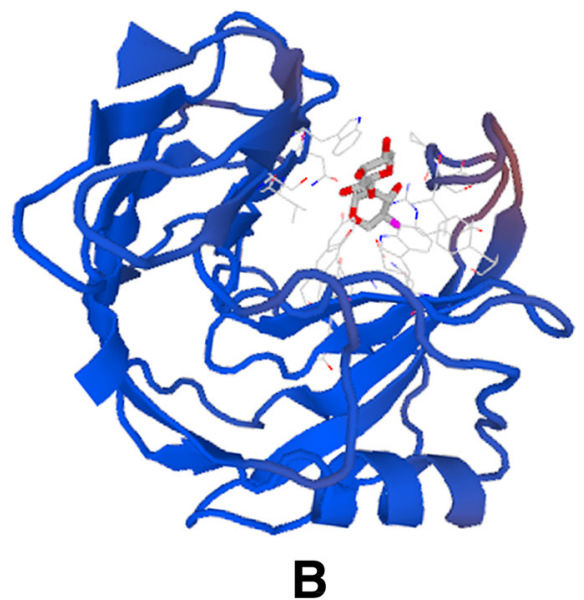

Figure 8 Homology-modelling of Xyn11A. A: Model of Xyn11A (the catalytic domain); B: Xyn11A model (the catalytic domain) showing the groove (housing the active site). 


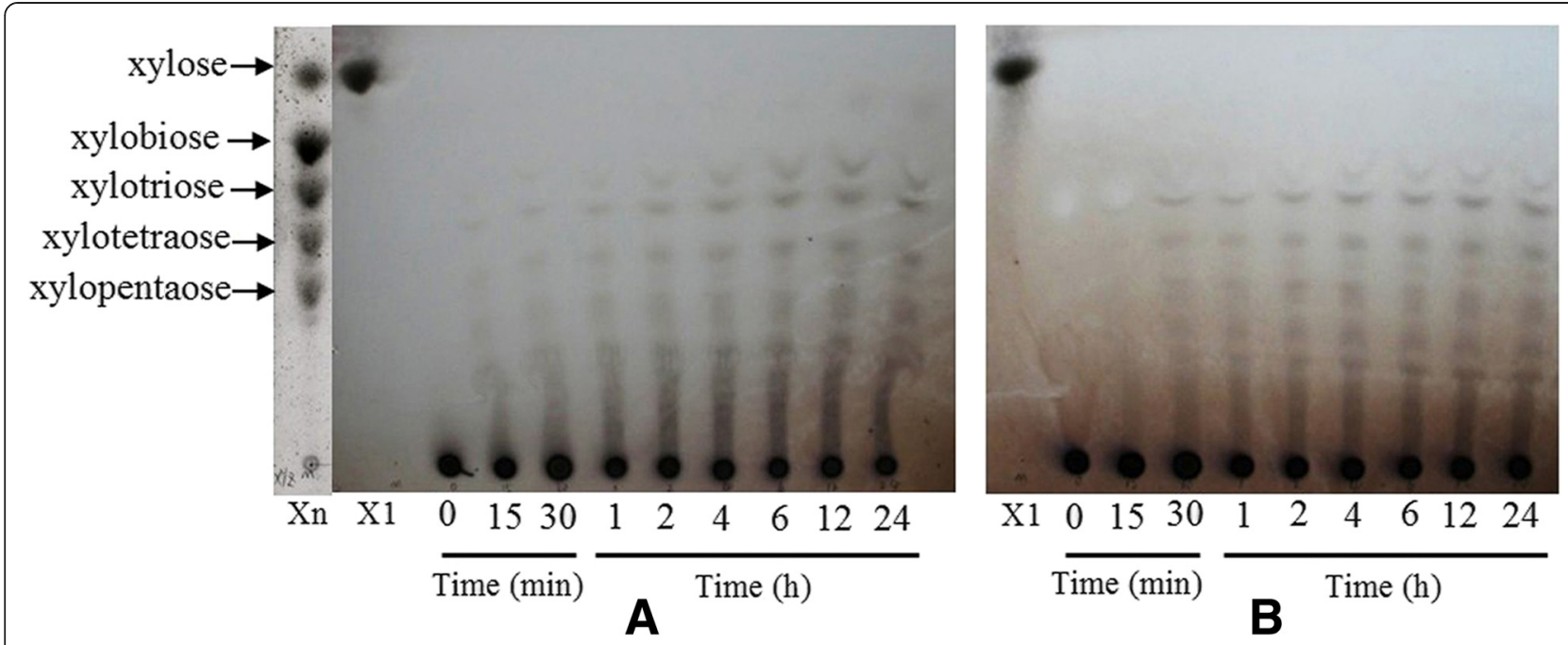

Figure 9 Thin-layer chromatogram of hydrolytic products of beechwood xylan by recombinant xylanases. A: Degradation of beechwood xylan by rXyn11A. B: Degradation of beechwood xylan by rXyn11A-(His) $)_{\text {. }}$

Japan). All other chemicals used were of reagent grade obtained from standard sources.

\section{Strains and plasmids}

Genomic DNA from T. fusca YX used in this study was purchased from ATCC (catalog BAA-629D-5). For cloning, pMD19-T vector (TaKaRa, Dalian, China) and E. coli DH5 $\alpha$ (Tiangen, Beijing, China) were used according to the manufacturers' recommendation. P. pastoris X-33 and pPICZ $\alpha-\mathrm{A}$ vector from EasySelect Pichia Expression Kit were purchased from Invitrogen (San Diego, CA, USA).

\section{Construction of the plasmid for Xyn11A expression}

In order to obtain the target gene $x y n A$ encoding the mature region of Xyn11A from $T$. fusca YX genome, three primers ( $x y A-f, x y A-r, x y A-h i s-r)$ were designed. The mature $x y n A$ gene was PCR amplified from genomic DNA of T. fusca YX with $x y A-f$ (5'-CGGAATTCGCCGTGACC TCCAACGAGA-3') as forward primer and $x y A-r$ (5'-GCTCTAGATTACTA GTTGGCGCTGCAGGACA$\left.3^{\prime}\right)$ as reverse primer (EcoRI and $X b a I$ restriction sites are denoted by the underline). For the PCR of His-tagged $x y n A$ gene, the reverse primer $x y$ A-his-r $\left(5^{\prime}\right.$-GCTCTAGATTA CTA ATGATGATGATGATGATGGTTGGCGCTGCA GGACA-3') was used (XbaI restriction site and (His) ${ }_{6}$-tag are denoted by the underline). Both PCR amplifications were carried out in a Thermal cycler (Bio-Rad, Hercules, CA, USA) as the following conditions: an initial denaturation at $95^{\circ} \mathrm{C}$ for $5 \mathrm{~min}, 30$ cycles of $95^{\circ} \mathrm{C}$ for $30 \mathrm{~s}, 55^{\circ} \mathrm{C}$ for $30 \mathrm{~s}$ and $72^{\circ} \mathrm{C}$ for $1 \mathrm{~min}$, followed by one cycle of $72^{\circ} \mathrm{C}$ for $10 \mathrm{~min}$. Afterwards, both PCR products were cloned into pMD19-T vector, yielding plasmids pMD19-xynA and pMD19-xynA-(His) ${ }_{6}$, respectively.

To obtain the secretive expression of rXyn11A and rXyn11A-(His) 6 , the plasmid pMD19- $x y n A / p M D 19-x y n A-$ (His) ${ }_{6}$ and $P$. pastoris-E. coli shuttle vector $\mathrm{pPICZ} \alpha-\mathrm{A}$ were both digested with EcoRI and XbaI and mutually ligated. After being transformed into $E$. coli DH5 $\alpha$, transformants were selected at $37^{\circ} \mathrm{C}$ on the low salt $\mathrm{LB}$ agar plates $(5 \mathrm{~g} / \mathrm{L}$ yeast extract, $10 \mathrm{~g} / \mathrm{L}$ tryptone, $5 \mathrm{~g} / \mathrm{L} \mathrm{NaCl}, 15 \mathrm{~g} / \mathrm{L}$ agar, and adjusted $\mathrm{pH}$ to 7.5$)$ containing $25 \mu \mathrm{g} / \mathrm{mL}$ Zeocin. The recombinant plasmids designated as pPICZ $\alpha-x y n A$ and pPICZ $\alpha-x y n A-(H i s)_{6}$ were obtained and sequenced by Invitrogen (Shanghai, China).

Table 2 Hydrolytic products concentration and percentage content of beechwood xylan by rXyn11A and rXyn11A-(His) 6

\begin{tabular}{lllllll}
\hline Enzyme & $\begin{array}{l}\text { Reaction } \\
\text { time }(\mathbf{h})\end{array}$ & \multicolumn{4}{l}{ Hydrolytic products concentrations $(\boldsymbol{\mu g} / \mathbf{m L})$ and percentage content } \\
\cline { 3 - 7 } & 6 & Xylose & Xylobiose & Xylotriose & Xylotetraose & xylopentaose \\
\hline rXyn11A & 6 & $12.0(0.4 \%)$ & $178.6(6.0 \%)$ & $630.8(21.3 \%)$ & $1007.9(34.1 \%)$ & $1130.2(38.2 \%)$ \\
& 12 & $16.9(0.5 \%)$ & $179.7(5.4 \%)$ & $661.5(19.9 \%)$ & $1113.1(33.6 \%)$ & $1347.6(40.6 \%)$ \\
& 24 & $24.1(0.7 \%)$ & $169.1(5.2 \%)$ & $649.6(20.0 \%)$ & $1152.6(35.5 \%)$ & $1255.3(38.6 \%)$ \\
rXyn11A-(His) & 6 & $12.5(0.8 \%)$ & $69.8(4.2 \%)$ & $295.3(18.0 \%)$ & $593.1(36.1 \%)$ & $672.2(40.9 \%)$ \\
& 12 & $12.8(0.7 \%)$ & $90.2(5.3 \%)$ & $317.8(18.5 \%)$ & $589.0(34.4 \%)$ & $704.0(41.1 \%)$ \\
& 24 & $17.4(1.1 \%)$ & $85.5(5.3 \%)$ & $298.9(18.5 \%)$ & $552.5(34.1 \%)$ & $664.4(41.0 \%)$ \\
\hline
\end{tabular}


Transformation of $P$. pastoris and screening of multi-copy transformants

Both the recombinant plasmids $\mathrm{pPIC} \alpha-x y n A$ and $\mathrm{pPICZ} \alpha-$ $x y n A$-(His) ${ }_{6}$ were linearized by restriction digestion with PmeI. Afterwards linearized DNA were transformed into $P$. pastoris $\mathrm{X}-33$ by electroporation using MicroPulser (Bio-Rad, Hercules, CA, USA) under the PIC setting. Then the $P$. pastoris transformants were selected on the YPDS agar plates $(10 \mathrm{~g} / \mathrm{L}$ yeast extract, $20 \mathrm{~g} / \mathrm{L}$ peptone, $20 \mathrm{~g} / \mathrm{L}$ dextrose, $20 \mathrm{~g} / \mathrm{L}$ agar and $1 \mathrm{M}$ sorbitol) containing $100 \mu \mathrm{g} / \mathrm{mL}$ Zeocin at $30^{\circ} \mathrm{C}$. After that, the transformants obtained were checked for the target gene integration using the extracted $P$. pastoris genomic DNA by PCR.

In order to get multi-copy transformants, the recombinant clones obtained were dotted onto the YPDS agar plates with higher Zeocin concentration (for example, $1000 \mu \mathrm{g} / \mathrm{mL}, 2000 \mu \mathrm{g} / \mathrm{mL}$ ) and incubated at $30^{\circ} \mathrm{C}$ for about 2 days.

\section{Expression of recombinant xylanases in $P$. pastoris}

For the expression of rXyn11A and rXyn11A-(His) 6 in recombinant $P$. pastoris, a single colony was inoculated into $25 \mathrm{~mL}$ BMGY medium $(10 \mathrm{~g} / \mathrm{L}$ yeast extract, $20 \mathrm{~g} / \mathrm{L}$ peptone, $100 \mathrm{mM}$ potassium phosphate $(\mathrm{pH} 6.0)$, $13.4 \mathrm{~g} / \mathrm{L} \mathrm{YNB}, 4 \times 10^{-4} \mathrm{~g} / \mathrm{L}$ biotin, $1 \%(\mathrm{v} / \mathrm{v})$ glycerol) in a $250 \mathrm{~mL}$ baffled flask and shaken $(220 \mathrm{rpm})$ at $29^{\circ} \mathrm{C}$ for about 18 hours. Then the cells were harvested by centrifuging at $3000 \times \mathrm{g}$ for $5 \mathrm{~min}$, and resuspended to an OD600 of 1.0 in BMMY medium $(10 \mathrm{~g} / \mathrm{L}$ yeast extract, $20 \mathrm{~g} / \mathrm{L}$ peptone, $100 \mathrm{mM}$ potassium phosphate $(\mathrm{pH} 6.0)$, 13.4 $\mathrm{g} / \mathrm{L}$ YNB, $4 \times 10^{-4} \mathrm{~g} / \mathrm{L}$ biotin, $0.5 \%$ (v/v) methanol) about $100 \mathrm{~mL}$ in a $1 \mathrm{~L}$ baffled flask, shaken at $29^{\circ} \mathrm{C}$ for 4 days. To maintain induction, $100 \%$ methanol was added to the culture to a final concentration of $0.5 \%$ every $24 \mathrm{~h}$ during the induction phase.

\section{Purification of recombinant xylanases}

For the purification of $\mathrm{rXyn} 11 \mathrm{~A}$, the culture supernatant was collected by centrifuging at $12000 \mathrm{rpm}$ for $5 \mathrm{~min}$. The ÄKTA avant 25 chromatography system (GE Healthcare, Little Chalfont, UK) was used for the purification. The supernatant was loaded on a Sephadex G-25 (GE Healthcare, Little Chalfont, UK) column which was pre-equilibrated with $20 \mathrm{mM}$ Tris- $\mathrm{HCl}$ buffer ( $\mathrm{pH}$ 8.2). Binding protein was eluted by the same buffer, the eluted protein was pooled and loaded on an anion-exchange Mono Q column which was equilibrated with $20 \mathrm{mM}$ Tris- $\mathrm{HCl}$ buffer ( $\mathrm{pH}$ 8.2). Then the Mono Q column was eluted by $20 \mathrm{mM}$ Tris- $\mathrm{HCl}$ buffer ( $\mathrm{pH}$ 8.2) containing $0.9 \mathrm{M} \mathrm{NaCl}$ at $2 \mathrm{ml} / \mathrm{min}$. Afterwards the purified protein was pooled and concentrated by the ultrafiltration with a $10 \mathrm{kDa}$ molecular weight cut-off membrane in the Amicon Ultra-15 centrifugal filter unit (Merck Millipore, MA, USA). The concentrated protein was stored at $4^{\circ} \mathrm{C}$.
For the purification of $\mathrm{rXyn} 11 \mathrm{~A}-(\mathrm{His})_{6}$, the harvested culture supernatant was filtrated with $0.22 \mu \mathrm{m}$ Millex-GP Filter Unit (Merck Millipore, MA, USA) after centrifuging the culture at $12000 \mathrm{rpm}$ for $5 \mathrm{~min}$, and then the filtrated supernatant was directly applied to Ni-NTA column (Merck, Darmstadt, Germany) which was equilibrated with $50 \mathrm{mM}$ PBS buffer (pH 7.4) at $1 \mathrm{~mL} / \mathrm{min}$. After the column was washed by $50 \mathrm{mM}$ PBS buffer $(\mathrm{pH} \mathrm{7.4)}$ ) at $2 \mathrm{~mL} / \mathrm{min}$, the enzyme was eluted successively with $50 \mathrm{mM}$ PBS buffer ( $\mathrm{pH}$ 7.4) containing $50 \mathrm{mM}$ and $100 \mathrm{mM}$ imidazole at $2 \mathrm{ml} / \mathrm{min}$ until A280 of the effluent kept constant. The eluted enzyme was pooled and concentrated by the ultrafiltration with a $10 \mathrm{kDa}$ molecular weight cut-off membrane in the Amicon Ultra-15 centrifugal filter unit (Merck Millipore, MA, USA). The purified enzyme was stored at $4^{\circ} \mathrm{C}$ for later use.

\section{Recombinant xylanase activity assays and protein determinations}

The culture collected at $96 \mathrm{~h}$ was centrifuged and the xylanases activities of culture supernatants were measured [40] according to the increase in reducing sugar given by the dinitrosalicylic acid (DNS) method [41] using xylose as a standard. The reaction mixture containing $900 \mu \mathrm{L}$ of $1 \%$ $(\mathrm{w} / \mathrm{v})$ beechwood xylan prepared in $0.2 \mathrm{M}$ glycine- $\mathrm{NaOH}$ buffer ( $\mathrm{pH} 8.0$ ) and $100 \mu \mathrm{L}$ of appropriately diluted xylanase enzyme solution was incubated at $80^{\circ} \mathrm{C}$ for $10 \mathrm{~min}$. After the reaction was stopped by adding $1000 \mu \mathrm{L}$ DNS solution (1\% 3, 5-dinitrosalicyclic acid, $20 \%$ potassium sodium tartrate, $1 \% \mathrm{NaOH}, 0.2 \%$ phenol, $0.05 \% \mathrm{Na}_{2} \mathrm{SO}_{3}$ ) to the mixtures, the samples were vortexed and boiled for $10 \mathrm{~min}$, followed by measuring the absorbance of $200 \mu \mathrm{L}$ sample at $540 \mathrm{~nm}$ using iMark Microplate Reader (Bio-Rad, Hercules, CA, USA). One unit of xylanase activity was defined as the amount of xylanase required to catalyze the release of $1 \mu \mathrm{mol}$ of xylose equivalent in $1 \mathrm{mi}$ nute under the assay condition. All of the xylanase activity values presented were averages obtained from triplicate measurements. The protein concentrations of culture supernatant were measured by Bio-Rad Protein Assay kit (Hercules, CA, USA) in triplicate.

\section{SDS-PAGE and xylanase activity staining}

SDS-PAGE was performed to detect the rXyn11A and rXyn11A-(His) ${ }_{6}$ with 5\% stacking gel and 15\% separating gel, and the protein bands were stained by Coomassie brilliant blue R-250.

Activity staining of recombinant xylanases was performed to display the visible xylanase activity bands on the gel [42] with slight modification. A 15\% separating gel with $0.1 \%$ xylan in it was prepared for separating proteins. The protein samples prepared for the activity staining were heated for $10 \mathrm{~min}$ at $60^{\circ} \mathrm{C}$ in the presence of $2 \% \mathrm{SDS}$, but without 2-mercaptoethanol. After electrophoresis, the gel 
was immediately washed by five successive 30 -min washes in $0.2 \mathrm{M}$ cold glycine- $\mathrm{NaOH}$ buffer ( $\mathrm{pH} 8.0$ ) with first two washes contained $25 \%(\mathrm{v} / \mathrm{v})$ isopropanol to remove the SDS. Then the gel was submersed in $0.2 \mathrm{M}$ glycine- $\mathrm{NaOH}$ buffer $(\mathrm{pH} 8.0)$ and incubated at $80^{\circ} \mathrm{C}$ for 1 h. Subsequently, the gel was stained in $0.2 \%$ Congo Red for $30 \mathrm{~min}$ and destained with $1 \mathrm{M} \mathrm{NaCl}$. Visible and clear activity bands against deep red background indicated the degradation of xylan.

\section{Deglycosylation of recombinant xylanases}

Both the purified rXyn11A and purified rXyn11A-(His) 6 were denatured by heating at $100^{\circ} \mathrm{C}$ for $10 \mathrm{~min}$, and then the endoglycosidase $\mathrm{H}$ was added and the reaction mixtures were incubated at $37^{\circ} \mathrm{C}$ for 2 hour. And all manipulations were according to the instructions of manufacturer. Subsequently, SDS-PAGE was performed to detect the separation of reaction products.

For the activity assay of deglycosylated recombinant xylanases, the endo $\mathrm{H}$ digestion reactions were slightly adapted and conducted as follows, the reaction mixtures containing endo $\mathrm{H}$ and purified $\mathrm{rXyn} 11 \mathrm{~A}$ or $\mathrm{rXyn} 11 \mathrm{~A}-(\mathrm{His})_{6}$ were incubated at $37^{\circ} \mathrm{C}$ for 4 hour without denaturation process. Subsequently, SDS-PAGE was performed to detect the separation of reaction products.

\section{Characterization of recombinant xylanases in $\mathrm{pH}$ and temperature}

To determine the optimal $\mathrm{pH}$ of rXyn11A and rXyn11A-(His) ${ }_{6}$ as well as deglycosylated rXyn11A and rXyn11A-(His) ${ }_{6}$, the xylanase activities were assayed in $0.2 \mathrm{M}$ various buffers such as MacIlvaine's buffer ( $\mathrm{pH}$ 3.0-7.0) and glycine- $\mathrm{NaOH}$ buffer ( $\mathrm{pH}$ 8.0-10.0) according to the standard assay method. For the determination of xylanases stabilities at various $\mathrm{pH}$ values, enzymes were pre-incubated in different $\mathrm{pH}$ buffers for $60 \mathrm{~min}$ at $55^{\circ} \mathrm{C}$. After cooling, the residual activities were measured as the standard method.

To measure the temperature optima of rXyn11A and rXyn11A-(His) $)_{6}$ as well as deglycosylated rXyn11A and rXyn11A-(His) $)_{6}$, the xylanase activities were determined among the temperature range from $30^{\circ} \mathrm{C}$ to $90^{\circ} \mathrm{C}$ by the standard assay method. For the determination of xylanases thermostability, enzymes were pre-incubated at different temperatures $\left(30-100^{\circ} \mathrm{C}\right)$ in $0.2 \mathrm{M}$ glycine- $\mathrm{NaOH}$ buffer $(\mathrm{pH} 8.0)$ for $30 \mathrm{~min}$, and the remained activities were measured as the standard method after cooling.

The thermostability of rXyn11A and rXyn11A-(His) 6 was further investigated under different incubated time at $70,80,90^{\circ} \mathrm{C}$. Aliquots were withdrawn at different time intervals $(0 \mathrm{~min}, 5 \mathrm{~min}, 10 \mathrm{~min}, 15 \mathrm{~min}, 20 \mathrm{~min}$, $25 \mathrm{~min}, 30 \mathrm{~min}, 40 \mathrm{~min}, 50 \mathrm{~min}, 60 \mathrm{~min}$ ). After cooling, the remnant activities were assayed according to the standard method.

\section{Structural modelling of Xyn11A}

The homology-modelling of Xyn11A was performed by Swiss-Model (http://swissmodel.expasy.org/) using the template (PDB entry 3zse), and the amino acid sequence identity was $99.47 \%[43,44]$.

\section{Analysis of hydrolysis of beechwood xylan by the recombinant xylanases}

To analyze the hydrolytic products of beechwood xylan, $1.0 \%$ beechwood xylan in $2 \mathrm{ml}$ of $0.2 \mathrm{M}$ glycine- $\mathrm{NaOH}$ buffer was mixed with $10 \mu \mathrm{L}$ of rXyn11A and $10 \mu \mathrm{L}$ of rXyn11A-(His) ${ }_{6}$, respectively. The reaction mixtures were incubated at $80^{\circ} \mathrm{C}$ for $24 \mathrm{~h}$. The aliquots at different time intervals were withdrawn and analyzed by both thin-layer chromatography (TLC) and high-performance ion chromatography (HPIC). For analysis of TLC, $10 \mu \mathrm{L}$ of the samples were spotted on the silica gel plates 60 F 254 (Merck, Darmstadt, Germany). A mixture containing xylose (X1), xylobiose (X2), xylotriose (X3), xylotetraose (X4) and xylopentaose (X5) dissolved in water was used as the standard. Chromatography was developed in butanolacetic acid-water (2:1:1, v/v) solvent system. After heating at $130^{\circ} \mathrm{C}$ for a couple of minutes in an oven, the plate was colorated by spraying with methanol-sulfuric acid mixture $(95: 5, \mathrm{v} / \mathrm{v})$ and heated in an oven at $130^{\circ} \mathrm{C}$ for $5 \mathrm{~min}$. The manipulations were modified from the method [45]. For analysis of HPIC, the samples at different time intervals $(6 \mathrm{~h}, 12 \mathrm{~h}, 24 \mathrm{~h})$ and standard xylooligosaccharides were analyzed with CarboPac ${ }^{\mathrm{TM}}$ PA200 anion-exchange column ( $3 \mathrm{~mm} \times 250 \mathrm{~mm}$; Dionex, CA, USA), pure water as mobile phase $(0.45 \mathrm{~mL} / \mathrm{min})$, and injection volumes were $10 \mu \mathrm{L}$. Sugar peaks were screened by ICS 5000 Electrochemical Detector (Dionex, CA, USA).

\section{Abbreviations}

rXyn11A: Recombinant Xyn11A; rXyn11A-(His)6: Recombinant Xyn11A with C-terminal His-tagged; CD: Catalytic domain; XBD: Xylan binding domain; X1: Xylose; X2: Xylobiose; X3: Xylotriose; X4: Xylotetraose; X5: Xylopentaose; PCR: Polymerase chain reaction; YPDS: Yeast extract peptone dextrose medium with $1 \mathrm{M}$ sorbitol; BMGY: Buffered glycerol-complex medium; BMMY: Buffered methanol-complex medium; PBS: Phosphate buffer saline; SDS-PAGE: Sodium dodecyl sulphate polyacrylamide gel electrophoresis; TLC: Thin-layer chromatography; HPIC: High-performance ion chromatography.

\section{Competing interests}

The authors declare that they have no competing interests.

\section{Authors' contributions}

LZ conceived and designed the study, performed the experiments, and drafted the manuscript. JG participated in the design of the study. RZ conceived of the study, participated in its design and helped to draft the manuscript. LZ, JG, YG, $\mathrm{XDL}, \mathrm{XHL}, \mathrm{RW}, \mathrm{ZZ}$ and $\mathrm{RZ}$ reviewed and edited the manuscript. All authors read and approved the final manuscript.

\section{Acknowledgements}

This research was supported by the 'Five-twelfth' National Science and Technology Support Program of China (2011BAD26B0403).

Received: 3 December 2014 Accepted: 6 March 2015

Published online: 18 March 2015 


\section{References}

1. Beg QK, Kapoor M, Mahajan L, Hoondal GS. Microbial xylanases and their industrial applications: a review. Appl Microbiol Biotechnol. 2001;56:326-38.

2. Subramaniyan S, Prema P. Biotechnology of microbial xylanases: enzymology, molecular biology, and application. Crit Rev Biotechnol. 2002;22:33-64

3. Li H, Kim NJ, Jiang M, Kang JW, Chang HN. Simultaneous saccharification and fermentation of lignocellulosic residues pretreated with phosphoric acid-acetone for bioethanol production. Bioresour Technol. 2009;100:3245-51.

4. Van Dyk JS, Pletschke BI. A review of lignocellulose bioconversion using enzymatic hydrolysis and synergistic cooperation between enzymes-Factors affecting enzymes, conversion and synergy. Biotechnol Adv. 2012;30:1458-80.

5. Wong KKY, Tan LUL, Saddler JN. Multiplicity of beta-1,4-xylanase in microorganisms-functions and applications. Microbiol Rev. 1988;52:305-17.

6. Beg QK, Bhushan B, Kapoor M, Hoondal GS. Enhanced production of a thermostable xylanase from Streptomyces sp. QG-11-3 and its application in biobleaching of eucalyptus kraft pulp. Enzyme Microb Tech. 2000;27:459-66.

7. Subramaniyan S, Prema P. Cellulase-free xylanases from Bacillus and other microorganisms. FEMS Microbiol Lett. 2000;183:1-7.

8. Techapun C, Poosaran N, Watanabe M, Sasaki K. Thermostable and alkaline-tolerant microbial cellulase-free xylanases produced from agricultural wastes and the properties required for use in pulp bleaching bioprocesses: a review. Process Biochem. 2003:38:1327-40.

9. Verma D, Satyanarayana T. Cloning, expression and applicability of thermoalkali-stable xylanase of Geobacillus thermoleovorans in generating xylooligosaccharides from agro-residues. Bioresour Technol. 2012;107:333-8.

10. Bae HJ, Kim HJ, Kim YS. Production of a recombinant xylanase in plants and its potential for pulp biobleaching applications. Bioresour Technol. 2008:99:3513-9.

11. Hu J, Arantes V, Saddler JN. The enhancement of enzymatic hydrolysis of lignocellulosic substrates by the addition of accessory enzymes such as xylanase: is it an additive or synergistic effect? Biotechnol Biofuels. 2011;4:36.

12. Henrissat B, Davies G. Structural and sequence-based classification of glycoside hydrolases. Curr Opin Struct Biol. 1997;7:637-44

13. Cantarel BL, Coutinho PM, Rancurel C, Bernard T, Lombard V, Henrissat B. The Carbohydrate-Active EnZymes database (CAZy): an expert resource for Glycogenomics. Nucleic Acids Res. 2009;37:D233-8.

14. Goncalves TA, Damasio ARL, Segato F, Alvarez TM, Bragatto J, Brenelli LB, et al. Functional characterization and synergic action of fungal xylanase and arabinofuranosidase for production of xylooligosaccharides. Bioresour Technol. 2012;119:293-9.

15. Cheng YF, Yang CH, Liu WH. Cloning and expression of Thermobifida xylanase gene in the methylotrophic yeast Pichia pastoris. Enzyme Microb Tech. 2005:37:541-6.

16. Bachmann SL, McCarthy AJ. Purification and cooperative activity of enzymes constituting the xylan-degrading system of Thermomonospora fusca. Appl Environ Microb. 1991:57:2121-30.

17. Irwin D, Jung ED, Wilson DB. Characterization and sequence of a Thermomonospora fusca xylanase. Appl Environ Microb. 1994;60:763-70.

18. Romanos MA, Scorer CA, Clare JJ. Foreign gene expression in yeast: a review. Yeast. 1992:8:423-88.

19. Ruanglek V, Sriprang $R$, Ratanaphan $N$, Tirawongsaroj $P$, Chantasigh D, Tanapongpipat S, et al. Cloning, expression, characterization, and high cell-density production of recombinant endo-1,4-beta-xylanase from Aspergillus niger in Pichia pastoris. Enzyme Microb Tech. 2007;41:19-25.

20. Wang Y, Zhang H, He Y, Luo H, Yao B. Characterization, gene cloning, and expression of a novel xylanase XYNB from Streptomyces olivaceoviridis A1. Aquaculture. 2007;267:328-34.

21. Jeya M, Thiagarajan S, Lee JK, Gunasekaran P. Cloning and expression of GH11 xylanase gene from Aspergillus fumigatus MKU1 in Pichia pastoris. J Biosci Bioeng. 2009;108:22-9.

22. Krainer F, Dietzsch C, Hajek T, Herwig C, Spadiut O, Glieder A. Recombinant protein expression in Pichia pastoris strains with an engineered methanol utilization pathway. Microb Cell Fact. 2012;11:22.

23. Vanz AL, Lunsdorf H, Adnan A, Nimtz M, Gurramkonda C, Khanna N, et al. Physiological response of Pichia pastoris GS115 to methanol-induced high level production of the Hepatitis B surface antigen: catabolic adaptation, stress responses, and autophagic processes. Microb Cell Fact. 2012;11:103.

24. Varnai A, Tang C, Bengtsson O, Atterton A, Mathiesen G, Eijsink V. Expression of endoglucanases in Pichia pastoris under control of the GAP promoter. Microb Cell Fact. 2014;13:57.
25. He J, Yu B, Zhang KY, Ding XM, Chen DW. Expression of endo-1, 4-beta-xylanase from Trichoderma reesei in Pichia pastoris and functional characterization of the produced enzyme. BMC Biotechnol. 2009;9:56-66.

26. Huang JL, Wang GX, Xiao L. Cloning, sequencing and expression of the xylanase gene from a Bacillus subtilis strain B10 in Escherichia coli. Bioresour Technol. 2006;97:802-8.

27. Baez A, Majdalani N, Shiloach J. Production of recombinant protein by a novel oxygen-induced system in Escherichia coli. Microb Cell Fact. 2014;13:50.

28. Songsiriritthigul C, Buranabanyat B, Haltrich D, Yamabhai M. Efficient recombinant expression and secretion of a thermostable GH26 mannan endo-1,4-beta-mannosidase from Bacillus licheniformis in Escherichia coli. Microb Cell Fact. 2010;9:20.

29. Li PZ, Anumanthan A, Gao XG, Ilangovan K, Suzara W, Duezguenes N, et al. Expression of recombinant proteins in Pichia Pastoris. Appl Biochem Biotechnol. 2007;142:105-24.

30. Zhao XH, Wang W, Wang FQ, Wei DZ. A comparative study of beta-1, 4-endoglucanase (possessing beta-1, 4-exoglucanase activity) from Bacillus subtilis LH expressed in Pichia pastoris GS115 and Escherichia coli Rosetta (DE3). Bioresour Technol. 2012;110:539-45.

31. Zhang F, Chen JJ, Ren WZ, Nie GX, Ming H, Tang SK, et al. Cloning, expression and characterization of an alkaline thermostable $\mathrm{GH} 9$ endoglucanase from Thermobifida halotolerans YIM 90462(T). Bioresour Technol. 2011;102:10143-6.

32. Wu JW, Filutowicz M. Hexahistidine (His 6 )-tag dependent protein dimerization: A cautionary tale. Acta Biochim Pol. 1999;46:591-9.

33. Cereghino $J \mathrm{~L}$, Cregg JM. Heterologous protein expression in the methylotrophic yeast Pichia pastoris. FEMS Microbiol Rev. 2000;24:45-66.

34. Grinna LS, Tschopp JF. Size distribution and general structural features of $\mathrm{N}$-linked oligosaccharides from the methylotrophic yeast, Pichia pastoris. Yeast. 1989;5:107-15

35. Zhang D, Lax AR, Raina AK, Bland JM. Differential cellulolytic activity of native-form and C-terminal tagged-form cellulase derived from Coptotermes formosanus and expressed in E. coli. Insect Biochem Mol Biol. 2009;39:516-22.

36. Sun JY, Liu MQ, Weng XY, Qian LC, Gu SH. Expression of recombinant Thermomonospora fusca xylanase A in Pichia pastoris and xylooligosaccharides released from xylans by it. Food Chem. 2007;104:1055-64.

37. Sevo M, Degrassi G, Skoko N, Venturi V, Ljubijankic G. Production of glycosylated thermostable Providencia rettgeri penicillin $\mathrm{G}$ amidase in Pichia pastoris. FEMS Yeast Res. 2002;1:271-7.

38. van Bueren AL, Otani S, Friis EP, Wilson KS, Davies GJ. Three-dimensional structure of a thermophilic family $\mathrm{GH} 11$ xylanase from Thermobifida fusca. Acta Crystallogr F. 2012;68:141-4.

39. Van Wyk N, Den Haan R, Van Zyl WH. Heterologous co-production of Thermobifida fusca Cel9A with other cellulases in Saccharomyces cerevisiae. Appl Microbiol Biotechnol. 2010;87:1813-20.

40. Bailey MJ, Biely P, Poutanen K. Interlaboratory testing of methods for assay of xylanase activity. J Biotechnol. 1992;23:257-70.

41. Miller GL. Use of Dinitrosalicylic acid reagent for determination of reducing sugar. Anal Chem. 1959:31:426-8.

42. Chen P, Buller CS. Activity staining of xylanases in polyacrylamide gels containing xylan. Anal Biochem. 1995;226:186-8.

43. Arnold K, Bordoli L, Kopp J, Schwede T. The SWISS-MODEL workspace: a web-based environment for protein structure homology modelling. Bioinformatics. 2006:22:195-201.

44. Biasini M, Bienert S, Waterhouse A, Arnold K, Studer G, Schmidt T, et al. SWISS-MODEL: modelling protein tertiary and quaternary structure using evolutionary information. Nucleic Acids Res. 2014;42:W252-8.

45. Zhang M, Jiang Z, Yang S, Hua C, Li L. Cloning and expression of a Paecilomyces thermophila xylanase gene in E. coli and characterization of the recombinant xylanase. Bioresour Technol. 2010;101:688-95. 